Revista Brasil. Bot., V.32, n.1, p.57-64, jan.-mar. 2009

\title{
Oil glands in the Neotropical genus Dahlstedtia Malme (Leguminosae, Papilionoideae, Millettieae)
}

\author{
SIMONE DE PÁDUA TEIXEIRA ${ }^{1,3}$ and JOECILDO FRANCISCO ROCHA ${ }^{2}$
}

(received: November 23, 2006; accepted: December 04, 2008)

\begin{abstract}
Oil glands in the Neotropical genus Dahlstedtia Malme - Leguminosae, Papilionoideae, Millettieae). Dahlstedtia pentaphylla (Taub.) Burkart and D. pinnata (Benth.) Malme belong to the Millettieae tribe and are tropical leguminous trees that produce a strong and unpleasant odour. In the present work, we investigated the distribution, development and histochemistry of foliar and floral secretory cavities that could potentially be related to this odour. The ultrastructure of foliar secretory cavities were also studied and compared with histochemical data. These data were compared with observations recorded for other species of Millettieae in order to gain a phylogenetic and taxonomic perspective. Foliar secretory cavities were only recorded for D. pentaphylla. Floral secretory cavities were present in the calyx, wings and keels in both species; in D. pinnata they also were found in bracteoles and vexillum. Such structures were found to originate through a schizogenous process. Epithelial cells revealed a large amount of flattened smooth endoplasmic reticula, well-developed dictyosomes and vacuoles containing myelin-like structures. Cavity lumen secretion stains strongly for lipids. Features of the secretory cavities studied through ultrastructural and histochemical procedures identify these structures as oil glands. Thus, if the odour produced by such plants has any connection with the accumulation of rotenone, as other species belonging to the "timbó" complex, the lipophilic contents of the secretory cavities of Dahlstedtia species take no part in such odour production. The presence, distribution patterns and frequencies of secretory structures in Dahlstedtia are taxonomically significant and may be utilized as a diagnostic character which justifies the separation of this genus into two species.
\end{abstract}

Key words - anatomy, development, histochemistry, secretory cavity, ultrastructure

RESUMO - (Glândulas de óleo no gênero neotropical Dahlstedtia Malme - Leguminosae, Papilionoideae, Millettieae). Dahlstedtia pentaphylla (Taub.) Burkart e D. pinnata (Benth.) Malme pertencem à tribo Millettieae e apresentam representantes arbóreos que produzem um odor forte e desagradável. Neste trabalho, foram investigados a distribuição, o desenvolvimento e a histoquímica de cavidades secretoras foliares e florais, que poderiam estar relacionadas a este odor. A ultra-estrutura das cavidades secretoras foliares também foi estudada e comparada aos resultados histoquímicos. Estes dados foram comparados a outros obtidos para espécies de Millettieae e discutidos sob perspectivas filogenética e taxonômica. Cavidades secretoras foliares foram observadas somente em $D$. pentaphylla. Cavidades secretoras florais foram observadas no cálice, nas alas e quilhas de ambas as espécies; em D. pinnata também foram encontradas nas bractéolas e no estandarte. As cavidades originaram-se por processo esquizógeno. As células do epitélio secretor apresentaram uma grande quantidade de retículo endoplasmático liso tubuloso, dictiossomos bem desenvolvidos e muitos vacúolos contendo figuras de mielina. A secreção presente no lúmen da cavidade é constituída por óleo, conforme indicam os caracteres histoquímicos e ultra-estruturais. Desta forma, o conteúdo das cavidades de Dahlstedtia não é responsável pelo odor forte e desagradável exalado pelas plantas, já que este está associado ao acúmulo de rotenona, comum em espécies pertencentes ao complexo "timbó". A ocorrência, o padrão de distribuição e a frequiência das cavidades secretoras apresentam valor taxonômico e podem ser utilizados como caracteres diagnósticos, justificando a separação das duas espécies no gênero.

Palavras-chave - anatomia, cavidade secretora, desenvolvimento, histoquímica, ultra-estrutura

\section{Introduction}

The genus Dahlstedtia Malme (Leguminosae, Papilionoideae) belongs to the predominantly tropical Millettieae tribe (Geesink 1981) and comprises two species: D. pinnata (Benth.) Malme (type species) and

1. Universidade de São Paulo, Faculdade de Ciências Farmacêuticas de Ribeirão Preto, Departamento de Ciências Farmacêuticas, Av. do Café s/nº, 14040-903 Ribeirão Preto, SP, Brazil.

2. Universidade Federal Rural do Rio de Janeiro, Instituto de Biologia, Departamento de Botânica, C.P. 74582, 23890-000 Seropédica, RJ, Brazil.

3._Corresponding author: spadua @ fcfrp.usp.br
D. pentaphylla (Taub.) Burkart (Burkart 1957), or is considered to be a monotypic genus (Hutchinson 1964, Geesink 1981, Vanni \& Rodriguez 1999).

Individuals of both species occur in low numbers in the Brazilian Atlantic Rainforest. Teixeira et al. (unpublished data) presumed that the high fruit and seed abortion rates of these taxa could be related to their scarcity. It is also worthwhile to note that these species are found in highly advanced degradated ecosystems, such as of the Brazilian Atlantic Rainforest.

Both species are commonly known in Brazil as timbó-guaraná, most probably because of their resemblance in odour to that of other legume Deguelia 
utilis (A. C. Sm.) A. M. G. Azevedo, which is considered to be the true timbó, and has been used in the Amazon region as a toxic substance for fish (Tozzi 1998). Many individuals of Dahlstedtia were discovered to be purposefully cut down inside otherwise standing forest. People who live in the seashore communities nearby the Atlantic Rainforest consider such smell strong and unpleasant, so the cutting down is a consequence of that.

Although there have been many field observations of this strong odour in Dahlstedtia, phytochemical studies of these species are rare in the literature. Only Garcez et al. (1988) report the presence of flavonoids in the roots of both species.

In this work, we investigated the distribution, development and histochemistry of foliar and floral secretory cavities in plants of $D$. pentaphylla and $D$. pinnata that could potentially be related to this odour. The ultrastructure of foliar secretory cavities were also studied and compared with histochemical data. These data were compared with observations recorded for other species of Millettieae in order to gain a phylogenetic and taxonomic perspective.

\section{Material and methods}

Study species - Dahlstedtia pentaphylla and D. pinnata are native to Brazil and have been recorded from Atlantic Rainforest. They comprise shrubs or trees, with conspicuous papillionate flowers. These species can be distinguished from each other by the corolla coloration, pink in D. pinnata and reddish in $D$. pentaphylla, and the presence of conspicuous lenticels on the floral branches of D. pentaphylla and their absence in D. pinnata (Teixeira \& Gabrielli 2000).

Plant material - Vegetative shoot apices, floral apices, leaflets, petiolules, petioles, pulvinus, buds and flowers of both species were collected from cultivated plants in Campinas (22 $54^{\prime}$ S, $47^{\circ} 03^{\prime}$ W), São Paulo State, Brazil. Material of D. pinnata was collected from natural populations at Parque Estadual da Serra do Mar, Picinguaba (2342' S, 4450' W) and Ubatuba (23 $26^{\prime}$ S, $45^{\circ} 04^{\prime}$ W), São Paulo State, Brazil and of D. pentaphylla at Serra da Graciosa, Antonina (2525'43' S, 4842'43” W), Paraná State, Brazil. The vouchers are deposited in the Herbarium of Universidade Estadual de Campinas (UEC), under the numbers 28637, 28746, 300 and 17936.

The following herbarium material was studied: $M$. $L$. Sekiama et al., 6610 (UEC), D. A. Great et al. 17 (UEC), N. Figueiredo et al. s/n (UEC 14713), P. H. Davis et al., s/ n (UEC 2934); G. Arbócz, s/n (UEC 32707).

Light microscopy - The material from herbarium specimens was treated with $2 \% \mathrm{KOH}$ solution for $2 \mathrm{~h}$, washed several times in distilled water (Smith \& Smith 1942) and stocked in $70 \%$ ethanol.
Fresh material, both cultivated and wild, was fixed in FAA 50 (formalin: acetic acid: ethanol 50\%), submitted to the standard techniques of infiltration with paraffin, sectioned (4-6 $\mu \mathrm{m})$ at rotary microtome, stained with Safranin and Alcian Blue and the slides mounted in synthetic resin (Gerlach 1969).

To detect phenolic compounds, material was fixed in formalin mixed with iron sulphide and then embedded in paraffin, sectioned $(8-10 \mu \mathrm{m})$, and mounted in synthetic resin (Jensen 1962). To detect lipids, material was fixed in buffered formalin (Lillie 1954), embedded in paraffin, sectioned (8-10 $\mu \mathrm{m})$, stained with Sudan Black B (Jensen 1962), Sudan III (Johansen 1940), and mounted in synthetic resin. To detect proteins, carbohydrates, and alkaloids material was fixed in FAA 50 (formalin: acetic acid: ethanol 50\%), embedded in paraffin, sectioned $(8-10 \mu \mathrm{m})$, stained with Aniline Blue Black (Fisher 1968), PAS Reagent (O'Brien \& McCully 1981), and Dragendorff Reagent (Svendsen \& Verpoorte 1983), respectively, and then mounted in synthetic resin. Histological sections from fresh material were also examined and compared with fixed material.

Transmission electron microscopy (TEM) - For ultrastructural studies, small pieces of leaflets were fixed with Karnovsky's solution (0.075 $\mathrm{M}$ in phosphate buffer, $\mathrm{pH} 7.2-7.4$, for $24 \mathrm{~h}$ ) (Karnovsky 1965), postfixed with osmium tetroxide (1\% in the same buffer for $1 \mathrm{~h}$ ), dehydrated in an acetone series and embedded in Araldite. Ultrathin sections were stained with 2\% uranyl acetate for 15 min (Watson 1958) and with lead citrate for $15 \mathrm{~min}$ (Reynolds 1963) and then examined using a Philips EM 208 electron microscope.

\section{Results}

Light microscopy - Foliar secretory cavities were only observed in Dahlstedtia pentaphylla. In the leaflet, they are visible as translucent dots, adjacent to veins (figure 1). They were present in the palisade (figure 2) and bundle parenchyma throughout the leaflet lamina, in the cortical parenchyma of the petiolule (figure 3 ) and petiole, and in the peripheral parenchyma of the pulvinus (figure 4). Floral secretory cavities are present in the calyx (figure 5), wings (figure 6) and keels of flowers in both species (figures 7,8 ); in D. pinnata they also are found in the bracteoles and the vexillum (figure 7). They were characterized by a lumen surrounded by a single layered epithelium (figures 2-6). When viewed in paradermic section, most of the cavities were isodiametrical (figure 1).

The cavities (foliar and floral) originated from a single cell of the ground meristem; this meristematic cell is distinguishable from other cells by its dense cytoplasm and prominent nucleus (figure 9). Initially, this single cell undergoes a periclinal division (figure 10), followed by two anticlinal divisions (figure 11), resulting in four cells 

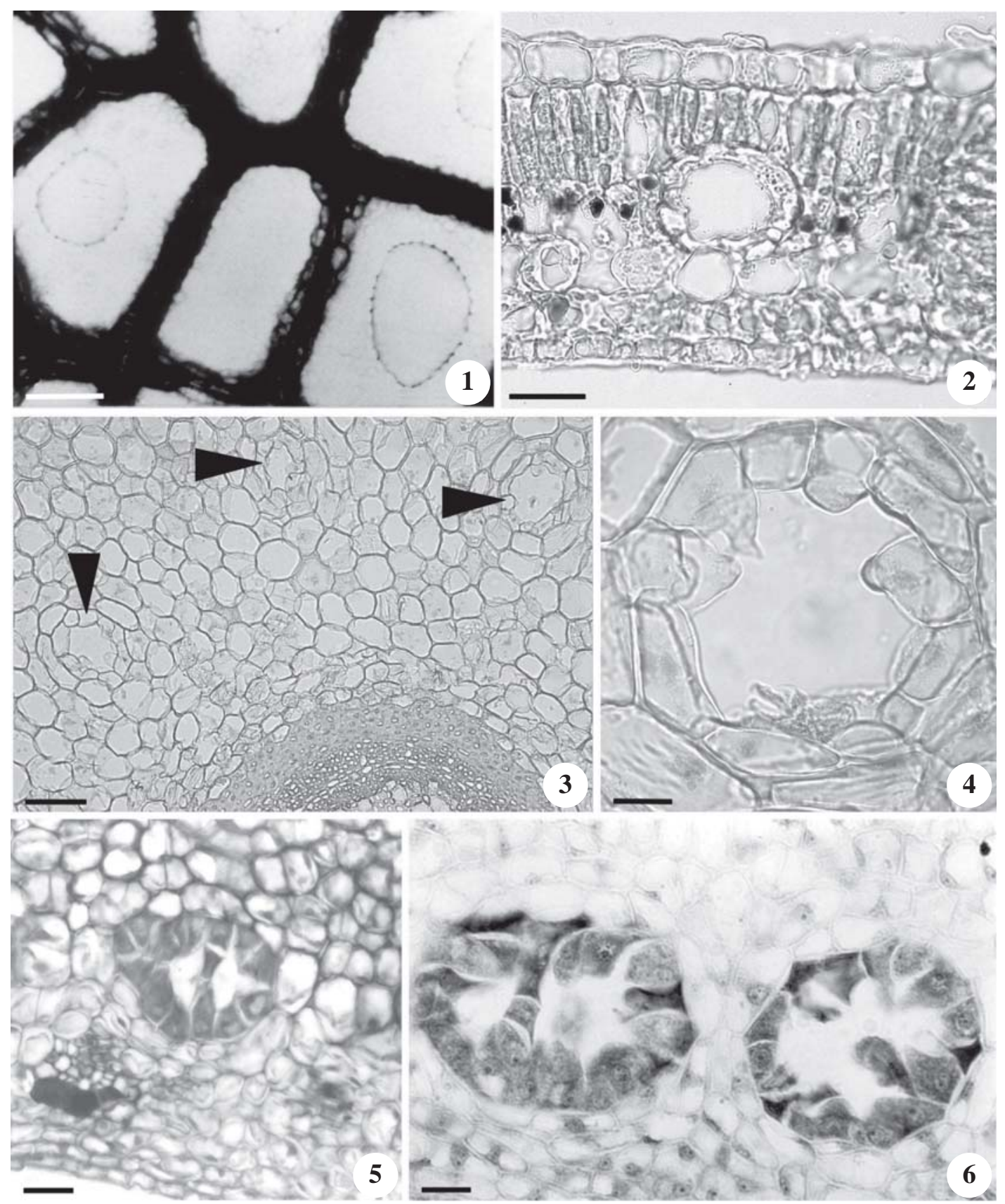

Figures 1-6. Light micrographs of the leaf (1-4) of Dahlstedtia pentaphylla and flower (5-6) of D. pinnata showing the structure of secretory cavities. 1. Abaxial surface view of cleared leaflets showing translucid dots. 2. Secretory cavities in the leaflet mesophyll. 3. Secretory cavities (arrow heads) in the cortical parenchyma of a petiolule. 4 . Detail of a secretory cavity in a pulvinus. 5. Trabeculate secretory cavity in a sepal. 6 . Detail of trabeculate secretory cavities in a wing. $B a r=30 \mu m(1,2)$, $42 \mu \mathrm{m}(3), 15 \mu \mathrm{m}(4,6), 43 \mu \mathrm{m}(5)$.

(figure 12). These divisions are followed by subsequent random divisions (figures 13, 14), cell enlargement (figures 14, 15) and separation of the cells from one another (figure 15), developing the isodiameric lumen by schizogeny (figure 16). The sequence of floral secretory cavity initiation is directed inward and follows the order of the floral whorls, commencing in the bracteoles, followed by the sepals and then finally the petals. Neighboring tissues are still differentiating when secretory cavity formation ceases. 

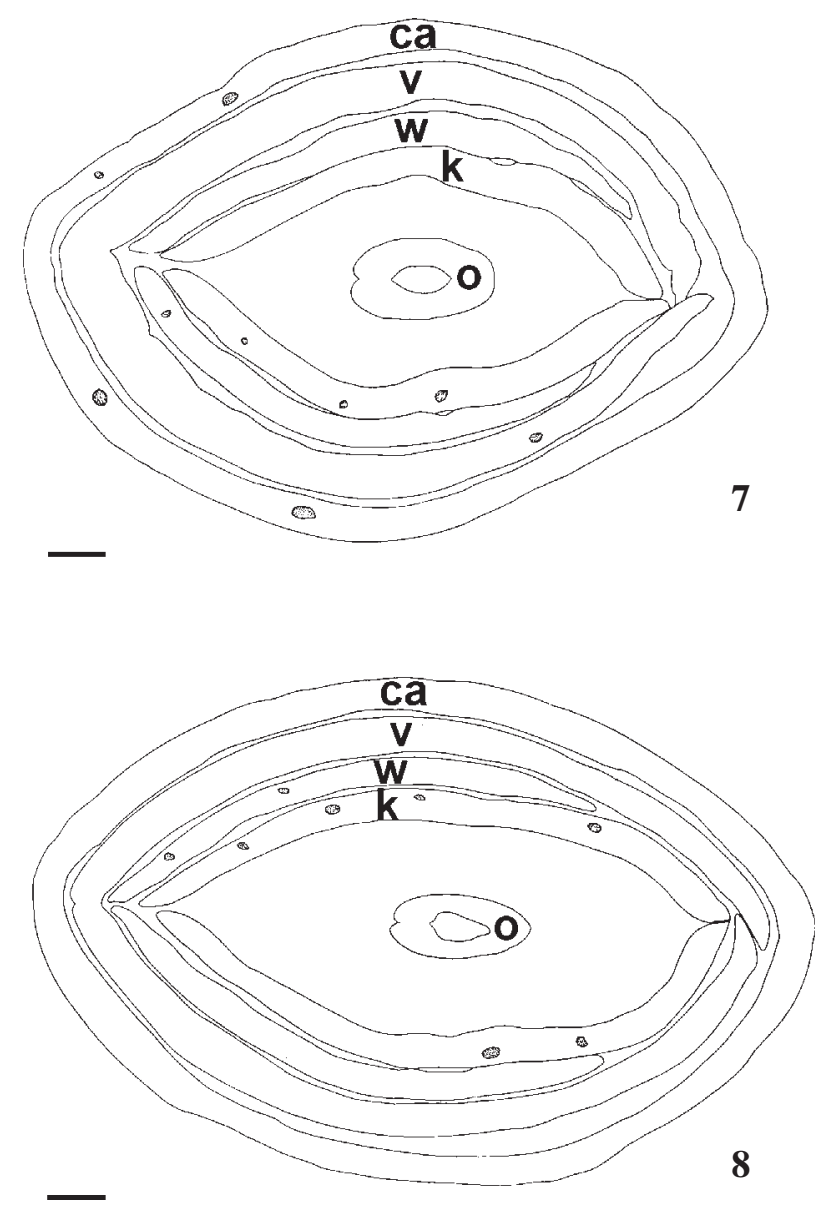

Figures 7-8. Transverse sections of floral buds showing the distribution of secretory cavities in the calyx and petal tips of Dahlstedtia. 7. D. pinnata. 8. D. pentaphylla $(\mathrm{w}=$ wing, $\mathrm{ca}=$ calix, $\mathrm{v}=$ vexyllum, $\mathrm{o}=$ ovary, $\mathrm{k}=\mathrm{keel}) . \mathrm{Bar}=0.5 \mathrm{~mm}$.

Epithelial cells of foliar and floral cavities show densely stained cytoplasm and larger nuclei than surrounding cells (figures 5,6). The cavity lumen contains an amorphous, yellowish-chestnut colored oil droplet. This droplet strongly stains with Sudan Black B and with Sudan III and is, therefore, a lipophilic secretion. Stain uptake with other tests was negative. Results from fixed and fresh specimens were not different. Cavities did not present secretion when tests were employed in cultivated plants.

Transmission electron microscopy (TEM) - Epithelial cells of active foliar secretory cavities are thin-walled and have a densely stained and abundant cytoplasm (figures 17-20). The cytoplasm is rich in polysomes, mitochondria with well-developed cristae, flattened rough endoplasmic reticulum (figure 19), dictyosomes with

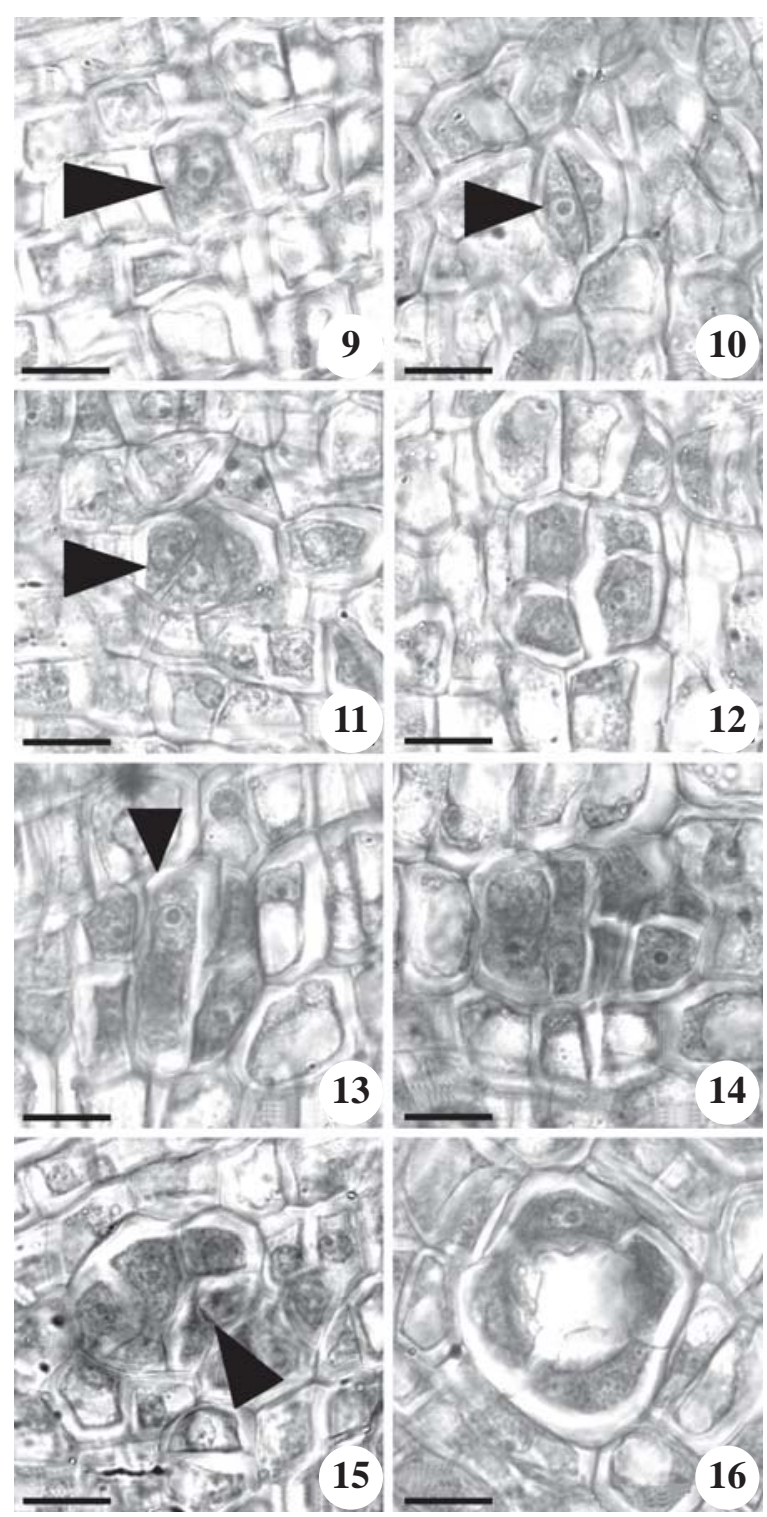

Figures 9-16. Light micrographs of Dahlstedtia pentaphylla cavity development. 9. Secretory cavity meristematic cell (arrow head) prior to division. This cell has dense cytoplasm and prominent nucleus. 10. First periclinal division (arrow head) of the single meristematic cell. 11. Four-celled precavity (arrow head) produced by two anticlinal divisions. 12. Six-celled pre-cavity produced by randomly directed divisions. 13. Enlargement of the pre-cavity cells (arrow head). 14. Cells begin to separate from one another. 15. A small space among cavity cells (arrow) appears, formed by schizogenous process. 16. Completely open cavity showing one-layered epithelium. Note that epithelial cells present conspicuous and central nuclei. Bar $=6 \mu \mathrm{m}$.

conspicuous cisternae and adjacent vesicles (figure 22) and abundant elements of smooth endoplasmic reticulum (figures 20, 21). 

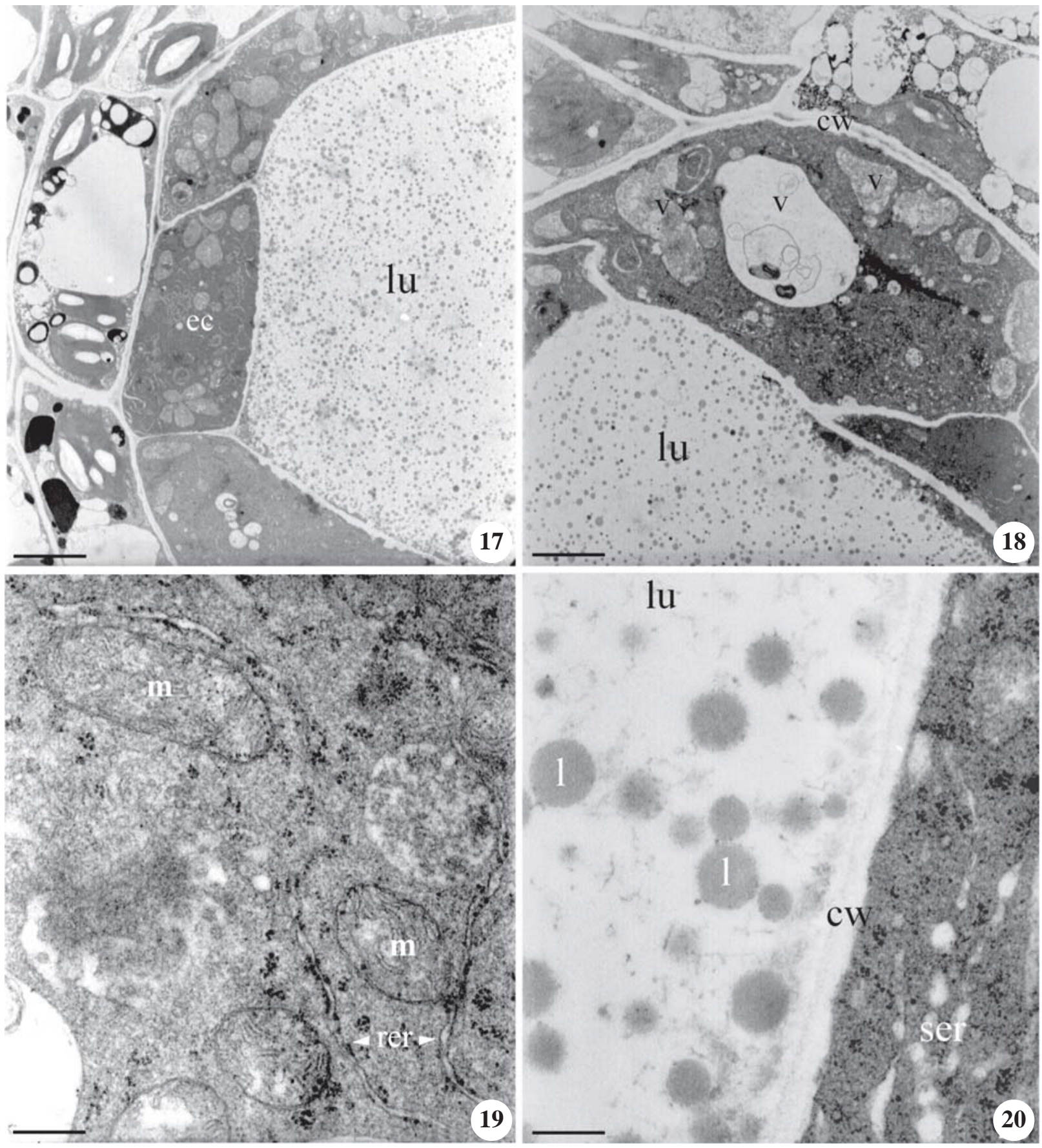

Figures 17-20. Electron micrographs of part of a secretory cavity in the leaf of Dahlstedtia pentaphylla. 17. Cytoplasm-rich epithelial cells (ec) and cavity lumen (lu) containing numerous lipid droplets. 18. Part of an epithelial cell at higher magnification with thin cell wall (cw), dense cytoplasm, vacuoles highly variable in shape and size (v), and lumen containing lipid droplets (lu). 19. Detail of cytoplasm of epithelial cell; cytoplasm rich in polysomes, mitochondriae (m) with well-developed cristae and extensive rough endoplasmic reticulum (rer). 20. Detail of the cell wall (cw), smooth endoplasmic reticulum (ser) and lumen containing lipid droplets (1). Bar $=1.0 \mu \mathrm{m}(17,18), 0.2 \mu \mathrm{m}(19,20)$.

The vacuoles are highly variable in shape and size (figure 18). Flocculate material was observed inside smaller vacuoles (figures 18, 22 and 23) while an amount of remnant membranous material forming myelin- like structures was observed inside larger vacuoles (figures 23).

The secretory cavity lumen contains numerous lipid droplets (figures 17, 18 and 20). 


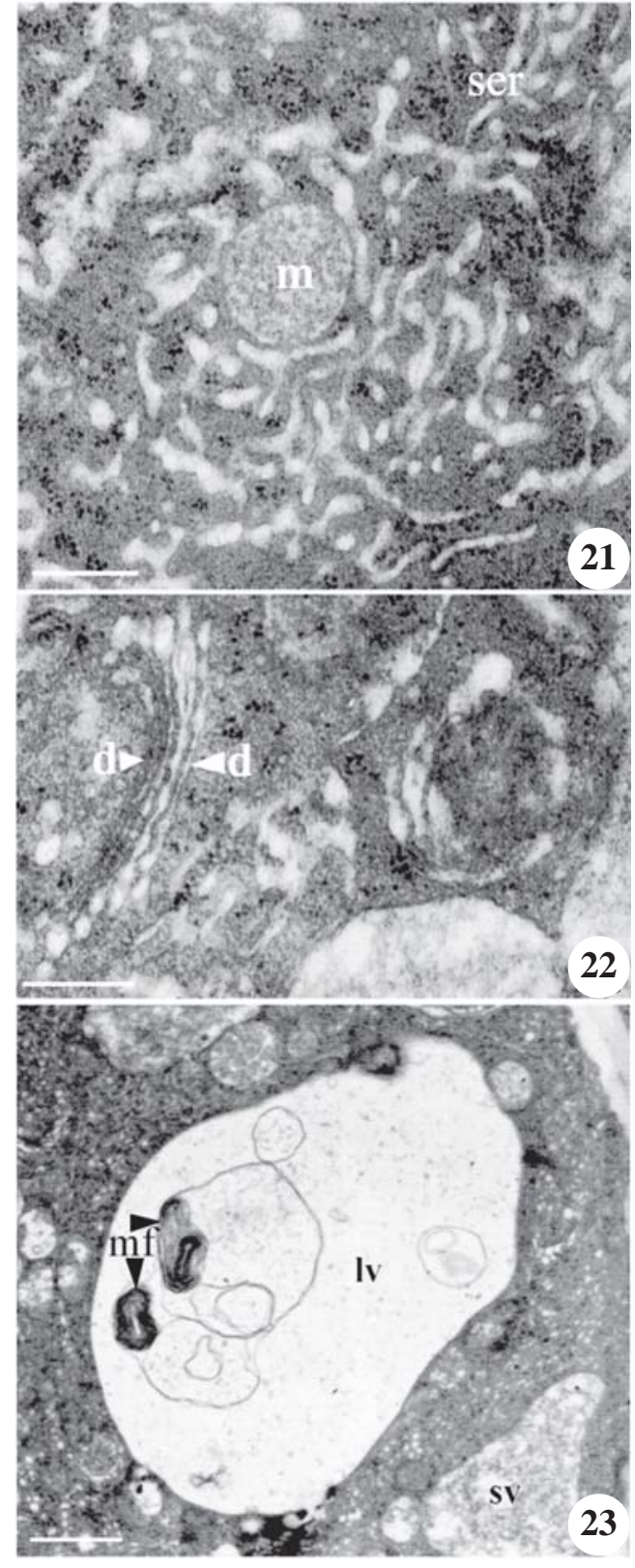

Figures 21-23. Electron micrographs of part of an epithelial cell of a secretory cavity in Dahlstedtia pentaphylla leaf. 21. Abundant elements of the smooth endoplasmic reticulum (ser) and mitochondriae (m). 22. Conspicuous dictyosomes (d). 23. Smaller vacuoles (sv) containing flocculate material and larger vacuoles (lv) containing remnant membranous material that formed myelin-like structures (mf). Bar $=0.2 \mu \mathrm{m}$ $(21,22), 0.5 \mu \mathrm{m}(23)$.

\section{Discussion}

The present study confirmed that the presence, distribution patterns and frequencies of secretory structures in Dahlstedtia are taxonomically significant, as reported by Metcalfe \& Chalk (1983) for secretory structures in general. The presence of secretory cavities in the leaf of D. pentaphylla and their absence from the leaves of $D$. pinnata, plus their differential distribution in the flowers of two species may be utilized as a diagnostic character to distinguish these species. Dahlstedtia has generally been considered to be monotypic (Hutchinson 1964, Geesink 1981, Vanni \& Rodríguez 1999), however Burkart (1957) considered it to comprise of two species. The latter view was supported by a biosystematic study, in which experimental pollinations showed that the two species are intersterile and are geographically isolated (Teixeira \& Ranga 2004). The two species however share a number of features such as similar stem and root anatomy (Teixeira \& Gabrielli 2000), embryogenesis (Teixeira et al. 2001) and floral development (Teixeira et al. unpublished data). A molecular phylogenetic study which includes these two species may help to clarify this taxonomic problem.

The position and type of secretory cavities have been used as diagnostic character of other tribes and genera within Leguminosae. Specifically, Turner (1986) based on the type and position of secretory cavities in the leaflet concluded that the Amorpheae and Psoraleeae (Papilionoideae) form two distinct groups. In Caesalpinia s. str. secretory cavities are restricted to the Poincianella group, and may be a significant taxonomic character at the subgeneric level (Lersten \& Curtis 1994).

Although secretory cavities are found in floral structures of both Dahlstedtia species, they are absent from the leaves of $D$. pinnata. This and the following observations lead us to suggest that at least in the more derived or specialized groups within Millettieae (coreMillettieae, Lavin et al. 1998, Hu et al. 2000), these taxa are predisposed to lose such secretory cavities. For example: (1) Garcez et al. (1988) reported a similar pattern at the chemical level, observing that flavonones and flavonols were produced in roots of $D$. pentaphylla but not in those of $D$. pinnata. The latter species instead produces flavones by a biosynthesis totally oriented toward dehydrogenation that is considered a derivate character-state. (2) Lonchocarpus, a genus very closely related to Dahlstedtia (Lavin et al. 1998), shows a similar presence/absence of secretory cavities such that only seven of 23 species studied had secretory cavities (Teixeira et al. 2000).

Based upon ultrastructural evidence, as presence of lipid droplets in lumen, numerous, well-developed smooth endoplasmic reticula in the cytoplasm of epithelial cells, and presence of myelin-like structures, plus histochemical evidence - positive staining for lipids with Sudan Black B and Sudan III in both fixed and 
fresh material, the content of the secretory cavities was considered to be lipophilic. Several authors mention endoplasmic reticulum as being one of the predominant cytoplasmic organelles of secretory cells associated with oil secretion (Fahn 1979, 1988, Monteiro et al. 1999), as well as myelin-like structures (Fahn \& Shimony 1998). According to Alberts et al. (1997) and Junqueira \& Carneiro (2000), both smooth and rough endoplasmic reticulum, plus dictyosomes are the main cellular synthesis sites. These organelles are involved in the secretion process and in addition the smooth endoplasmic reticulum is specifically involved in lipid synthesis. In this study smooth endoplasmic reticulum was found to be predominant in epithelial cells of the foliar secretory cavities of Dahlstedtia. Such a feature testifies the quantities of lipid droplets found in the lumen of secretory cavities. Such secretory cavities for predominantly lipophilic substances have already been reported in other species of Leguminosae (Solereder 1908, Metcalfe \& Chalk 1950).

Species belonging to the timbó complex contain rotenoids (group of flavones - phenolic compounds), i.e., substances responsible for a strong and unpleasant odour and which are toxic to fish. Such substances have not yet been reported in secretory structures and their transport and accumulation seem to take place in the vascular system. If the odour produced by such plants has any connection with the accumulation of rotenone, the lipophilic contents of the secretory cavities of Dahlstedtia species therefore take no part in such odour production (see the histochemical tests which were negative to phenolic compounds). It should be noticed that the leaves of both species produce strong odor and only those of $D$. pentaphylla presented secretory cavities.

No differences in the major composition of gland contents were found between the vegetative and reproductive organs of Dahlstedtia pentaphylla, nor between the floral organs of the two Dahlstedtia species. Identification and isolation of substances found in the content of secretory cavities of these species would bring a better understanding to the role of such metabolites inside the plant.

Cultivated plants of Dahlstedtia species lacked secretion in their cavities. One could hypothetize that plants under natural conditions would be subjected to higher stressful conditions as competition for light, water and mineral nutrients, as well as herbivore attacks than plants cultivated in botanical gardens or parks, and that would potentially lead to a higher production of metabolites (Fahn 1979). These metabolites can play a core role in plant defense mechanisms against phytophagous species (Fahn 1979, Harborne 1998). Controlled experiments on morphology and physiology, however, would be necessary to confirm such a hypothesis.

Acknowledgments - We thank Matthew Lavin and Rodrigo Augusto Santinelo Pereira for the critical reading of the manuscript, Maria Dolores Seabra Ferreira and José Augusto Maulin (TEM Laboratory/BCMBP, FMRP-USP) for the technical assistance, Fernando Santiago dos Santos for the English review and Silvia Rodrigues Machado for help with electron micrographs.

\section{References}

ALBERTS, B., BRAY, D., LEWIS, J., RAFF, M., ROBERTS, K. \& WATSON, J.D. 1997. Molecular biology of the cell. Garland Publishing, New York.

BURKART, A. 1957. Dahlstedtia pentaphylla (Taub.) Burkart, nov. comb. Darwiniana 11:269.

FAHN, A. 1979. Secretory tissues in plants. Academic Press, New York.

FAHN, A. 1988. Secretory tissues in vascular plants. New Phytologist 108:229-257.

FAHN, A. \& SHIMONY, C. 1998. Ultrastructure and secretion of the secretory cells of two species of Fagonia L. (Zygophyllaceae). Annals of Botany 81:557-565.

FISHER, D.B. 1968. Protein staining of ribboned epon sections for light microscopy. Histochemie 16:92-96.

GARCEZ, F.R., SCRAMIN, S., NASCIMENTO, M.C. \& MORS, W.B. 1988. Prenylated flavonoids as evolutionary indicators in the genus Dahlstedtia. Phytochemistry 27:1079-1083.

GEESINK, R. 1981. Tephrosieae (Benth.) Huch. In Advances in legume systematics, part 1 (R.M. Polhill \& P.H. Raven, eds.). Royal Botanic Gardens, Kew, p.245-260.

GERLACH, G. 1969. Botanische Mikrotechnik, eine Einfuhrung. Gorg Thieme, Stuttgard.

HARBORNE, J.B. 1998. Phytochemical methods - A guide to modern techniques of plant analysis. $3^{\text {rd }}$ ed. Academic Press, London.

HU, J.-M., LAVIN, M., WOJCIECHOWSKI, M.F. \& SANDERSON, M.J. 2000. Phylogenetic systematics of the tribe Millettieae (Leguminosae) based on chloroplast trnK/matK sequences and its implications for evolutionary patterns in Papilionoideae. American Journal of Botany 87:418-430.

HUTCHINSON, J. 1964. The genera of flowering plants (Angiospermae)-Dicotyledons. Clarendon Press, Oxford.

JENSEN, W.A. 1962. Botanical histochemistry: principles and practice. W.H. Freeman, San Francisco.

JOHANSEN, D.A. 1940. Plant microtechnique. McGrawHill Book Company Inc., New York.

JUNQUEIRA, L.C. \& CARNEIRO, J. 2000. Biologia celular e molecular. 7a ed. Guanabara Koogan, Rio de Janeiro. 
KARNOVSKY, M.J. 1965. A formaldehyde-glutaraldehyde fixative of high osmalarity for use in eletron microscopy. Journal of Cell Biology 27:137A-138A.

LAVIN, M., ESHBAUGH, E., HU, J.-M., MATHEWS, S. \& SHARROCK, R.A. 1998. Monophyletic subgroups of the tribe Millettieae (Leguminosae) as revealed by phytochrome nucleotide sequence data. American Journal of Botany 85:412-433.

LERSTEN, N.R. \& CURTIS, J.D. 1994. Leaf anatomy in Caesalpinia and Hoffmannseggia (Leguminosae, Caesalpinioideae) with emphasis on secretory structures. Plant Systematics and Evolution 192: 231-255.

LILLIE, R.D. 1954. Histopathologic technic and practical histochemistry. McGraw-Hill Book Co, New York.

METCALFE, C.R. \& CHALK, L. 1950. Anatomy of the Dicotyledons: leaves, stem and wood in relation to taxonomy with notes one economic uses. Clarendon Press, Oxford.

METCALFE, C.R. \& CHALK, L. 1983. Anatomy of the Dicotyledons. Wood, structure and conclusion of the general introduction. Clarendon Press, Oxford.

MONTEIRO, W.R., FAHN, A., CALDEIRA, W. \& CASTRO, M.M. 1999. Ultrastructural observation on the foliar secretory cavities of Porophyllum lanceolatum DC. (Asteraceae). Flora 194:113-126.

O'BRIEN, T.P. \& MCCCULLY, M.E. 1981. The study of plant structure. Principles and selected methods. Termorcarphy Ltd., Melbourne.

REYNOLDS, E.S. 1963. The use of lead citrate at high $\mathrm{pH}$ as an electron-opaque stain in electron microscopy. Journal of Cell Biology 17:208.

SMITH, F.H. \& SMITH, E.C. 1942. Anatomy of the inferior ovary of Darbya. American Journal of Botany 29:464-471.
SOLEREDER, H. 1908. Systematic anatomy of the Dicotyledons. A handbook for laboratories of pure and applied Botany. Translated by Boodle LA, Fritsch FG. Clarendon Press, Oxford.

SVENDSEN, A.B. \& VERPOORTE, R. 1983. Cromatography of alkaloids. Elsevier Scientific Publishing Company, New York.

TEIXEIRA, S.P., CASTRO, M.M. \& TOZZI, A.M.G.A. 2000. Secretory cavities and pellucid dots in leaflets of Lonchocarpus (Leguminosae, Papilionoideae, Millettieae). Plant Systematics and Evolution 221:61-68.

TEIXEIRA, S.P. \& GABRIELLI, A.C. 2000. Anatomia do eixo vegetativo de Dahlstedtia pinnata (Benth.) Malme e D. pentaphylla (Taub.) Burkart (Leguminosae, Papilionoideae). Revista Brasileira de Botânica 23:1-11.

TEIXEIRA, S.P., PRAKASH, N. \& RANGA, N.T. 2001. Ovule and early seed development related to seed abortion in Dahlstedtia pinnata and D. pentaphylla (Leguminosae, Papilionoideae). Phytomorphology 51:41-50.

TEIXEIRA, S.P. \& RANGA, N.T. 2004. Biosystematics of the genus Dahlstedtia Malme (Leguminosae, Papilionoideae, Millettieae). Brazilian Journal of Botany 27:37-45.

TOZZI, A.M.G.A. 1998. A identidade do timbó-verdadeiro: Deguelia utilis (A.C.Sm.) A.M.G.Azevedo (Leguminosae -Papilionoideae). Brazilian Journal of Biology 58:511-516.

TURNER, G.W. 1986. Comparative development of secretory cavities in the tribes Amorpheae and Psoraleeae (Leguminosae: Papilionoideae). American Journal of Botany 73:1178-1192.

VANNI, R.O. \& RODRÍGUEZ, M. 1999. Dahlstedtia (Leguminosae, Millettieae) nueva cita para la flora argentina. Hickenia 3:5-8.

WATSON, M.L. 1958. Staining of tissue sections for electron microscopy with heavy metals. Journal of Biophysical, Biochemistry and Cytology 4:475. 